\title{
LICHENS COLLECTED DURING A DUTCH BOTANICAL EAST GREENLAND EXPEDITION TO THE ANGMAGSSALIK AREA IN 1966
}

\author{
F. J. A. DANIËLS \\ Botanisch Museum en Herbarium, Utrecht
}

\section{INTRODUCTION}

In the summer of 1966 three students, bachelors in botany, of the State University of Utrecht, Netherlands, made botanical investigations in the Angmagssalik area $\left(65^{\circ}\right.$ N.lat. $-67^{\circ} 20^{\prime}$ N. lat.) in South-east Greenland. The main purpose was to carry out floristical and ecological investigations, while special attention was paid to the altitudinal belts in the vegetation on mountain slopes. The fieldwork will be continued in 1968 .

From the botanical collection the lichens were identified by the author and are listed here, except some critical species of which the determinations have not been finished yet. The number of samples collected amounts to ca. 300, most of them taken from vegetation analyses. All samples will be incorporated in the Herbarium of the State University of Utrecht, Netherlands.

At present the knowledge of the lichen flora of Greenland as a whole is still rather imperfect. Intensive lichenological investigations have been carried out in several parts of Greenland (cf. DAHL 1950, DAHL c.s. 1937, HANSEN 1962 and LYNGE \& SCHOLANDER 1937), but there are still many areas of which the lichen flora is fully unknown or very poorly known.

The Angmagssalik area belongs to the latter group. In his voluminous paper concerning botanical investigations between $65^{\circ} 30^{\prime}$ N.lat. and $67^{\circ} 20$ N.lat. in East Greenland in the years 1898-1902 KRUUSE (1912) only mentions 15 lichen species of which 8 were also found in 1966. As the greatest part of Kruuse's lichen collection was lost and he does not mention where the rest is to be found, it is impossible to check his field determinations. Therefore, as in the other publications concerning lichens from South-east Greenland, they are left out of account here. Böcher has collected a small number of lichens, mainly in Blomsterdalen, a little valley behind the Angmagssalik settlement, during the Scoresby Sound Committee's 2nd East Greenland Expedition in 1932 to King Christian IX's Land. His collection was identified by LYNGE (1933) and included only 15 species, all macrolichens. A Dutch ornithologist, Tinbergen, gathered some lichens in 1932, of which only Stereocaulon paschale (L.) Hoffm. var. alpinum (Laur.) Mudd. (Det. I.M. Lamb, 1952) has been preserved in the Herbarium of the State University of Utrecht. In 1933 the Danish geologist Bøgvad collected 15 species of lichens, mostly crustaceous, on Storøen ( $66^{\circ} 15^{\prime}$ N.lat.) and Knutsen found Lecanora polytropa in Angmagssalik (DAHL, LYNGE \& SCHOLANDER 1937). 
Although in 1966 only two localities were visited and the list of species, including 56 species, is not complete, it is rather representative since the sample areas are situated in the two floristical provinces to which the area belongs (BöCHER, HOLMEN \& JAKOBSON 1959). Eighteen of them have been recorded earlier by DAHL, LYNGE \& SCHOLANDER (1937) and LYNGE (1933), 38 of them are as far as could be ascertained new to the area. One species, Cladonia cyanipes (Somm.) Nyl. is a first record for South-east Greenland (DAHL, LYNGE \& SCHOLANDER 1937 and LAMB 1940).

The total number of lichens recorded from the Angmagssalik area now amounts to ca. 70, i.e. about a third of the total number for South-east Greenland, but surely it will be considerably higher when if the lichenological investigations are intensified and more localities are visited.

\section{LIST OF LOCALITIES}

Locality I: The vicinity of the Angmagssalik settlement $\left(65^{\circ} 35^{\prime}-38^{\prime}\right.$ N.lat. $37^{\circ} 38^{\prime}-44^{\prime}$ W.long.), a coastal area with an oceanic low-arctic climate.

Locality II: The inner part of the Tasilaq fjord $\left(66^{\circ} 02^{\prime}-07^{\prime}\right.$ N.lat. $-36^{\circ} 58^{\prime}-$ $37^{\circ} 03^{\prime}$ W.long.), an inland area with a continental low-arctic climate.

\section{LIST OF SPECIES}

The nomenclature is in accordance with Hale \& Culberson (1966) as far as the species occur within the area of North America which is comprised by that work. As to the nomenclature of Umbilicaria virginis GAMS (1967) is followed. An asterisk before a species name indicates that the species is collected previously in the Angmagssalik area (DAHL, LYNGE \& SCHOLANDER 1937 and LYNGE 1933). The localities are indicated by the Roman numbers I and 11 .

Alectoria Ach.

1 Alectoria minuscula Nyl.

2 Alectoria nigricans (Ach.) Nyl.

3 Alectoria ochroleuca (Hoffm.) Mass.

4 Alectoria pubescens (L.) R.H. Howe. Candelariella Müll. Arg.

5 *Candelariella vitellina (Ehrh.) Müll. Arg.

Cetraria Ach.

6 Cetraria commixta (Nyl.) Th. Fr. I

7 Cetraria delisei (Bory) Th. Fr. I

8 Cetraria ericetorum Opiz.

9 Cetraria hepatizon (Ach.) Vain.

10 *Cetraria islandica (L.) Ach.

11 Cetraria nivalis (L.) Ach.

Cladonia Wigg.

12 Cladonia alpicola (Flot.) Vain. II

13 Cladonia amaurocraea (Flörke) Schaer.
14 * Cladonia bellidiflora (Ach.)

I, II Schaer. I, II

15 Cladonia cf. cariosa (Ach.) Spreng. I, II

16 Cladonia chlorophea (Flörke) Spreng. I, II

17 Cladonia crispata (Ach.) Flot. I, II

I, II 18 Cladonia cyanipes (Somm.) Nyl. I

19 *Cladonia deformis (L.) Hoffm. I, II

20 *Cladonia ecmocyna (Ach.) Nyl. I, II

21 Cladonia gracilis (L.) Willd. I, II

22 *Cladonia lepidota Nyl. . I, II

23 Cladonia macrophyllodes Nyl. I, II

24 *Cladonia mitis Sandst. I, II

25 *Cladonia pleurota (Flörke) Schaer.

26 * Cladonia rangiferina Wigg I, II

27 *Cladonia uncialis (L.) Wigg. I, II Cornicularia (Schreb.) Hoffm.

28. Cornicularia aculeata (Schreb.) Ach. 
Lecidea Ach.

29 Lecidea demissa (Rutstr.) Ach. II

30 *Lecidea dicksonii (Gmel.) Ach. I

Lepraria Ach.

31 Lepraria neglecta (Nyl.) Lett. I, II

Nephroma Ach.

32 Nephroma arcticum (L.) Torss.

Ochrolechia Mass.

33 Ochrolechia frigida (Sw.) Lynge I, II

Pannaria Del.

34 Pannaria pezizoides (G. Web.) Trev.

Parmelia Ach.

35 Parmelia alpicola Th. Fr.

Peltigera Willd.

36 Peltigera aphthosa (L.) Willd.

37 Peltigera canina (L.) Willd.

38 Peltigera malacea (Ach.) Funck. I, II

39 Peltigera membranacea (Ach.) Funck.

40 Peltigera cf. scabrosa Th. Fr.

41 Peltigera spuria (Ach.) DC.

Pertusaria DC.

42 *Pertusaria oculata (Dicks.) Th. Fr.

Psoroma (Ach.) Ach. ex Michx.

I
$43 *$ Psoroma hypnorum (Vahl) S.

Gray.

I, II

Rinodina (Ach.) S. Gray.

44 Rinodina mniaraea (Ach.) Körb. II

Solorina Ach.

45 * Solorina crocea (L.) Ach. I, II

Sphaerophorus Pers.

46. Sphaerophorus fragilis (L.) Pers. II

Stereocaulon Hoffm.

47 *Stereocaulon alpinum Laur. I, II

48 Stereocaulon botryosum Ach. II

49 "Stereocaulon paschale (L.)

Hoffm.

I, II

50 Stereocaulon vesuvianum Pers. var. denundatum (Flörke) Lamb. I, II

Thamnolia Ach. ex Schaer.

51 Thamnolia subuliformis (Ehrh.) W. Culb.

I, II

Umbilicaria Hoffm.

I, II $\quad 52 *$ Umbilicaria cylindrica (L.) Del. I, II

I, II 53 Umbilicaria deusta (L.) Baumg. I, II

54 * Umbilicaria hyperborea (Ach.) Ach.

I

55 Umbilicaria proboscidea (L.) Schrad.

56 Umbilicaria virginis Schaerer I

\section{ACKNOWLEDGEMENTS}

The author wishes to express his gratitude to Mr. Kjeld Hansen, M. Sc., of the Institute of Systematic Botany, the Royal Veterinary and Agricultural College, Copenhagen, for his kind help in the determinations of several species of the genus Stereocaulon and to Mr. Skytte Christiansen, M. Sc., of the Botanical Museum of the University of Copenhagen for his advice in East Greenland lichenological literature.

Furthermore he wishes to thank Prof. Th. Sørensen, Ph. D., the director to the Museum mentioned above for providing facilities in the Arctic Herbarium during two weeks in April 1967.

Finally he thanks Messrs. Drs. E. Hennipman and Dr. R. A. Maas Geesteranus of the State Herbarium, Leiden, Netherlands for their help in determinations of several species.

\section{REFERENCES}

Böcher, T. W., K. Holmen \& K. JACOBSEN (1957): A synoptical study of the Greenland flora. Medd. om Gronl. 163, 1:1-32.

DAHL, E. (1950): Studies in the macrolichen flora of Southwest Greenland. Medd. om Gronl. 150, 2:1-176.

Dahl, E., B. LyNGe \& P. F. Scholander (1937): Lichens from Southeast Greenland. Skr. Svalb. og Ishavet 70:1-76.

Gams, H. (1967): Kleine Kryptogamenflora, III: Flechten. 1-244. Gustav Fischer Verlag. Stuttgart.

Hale, M. E. Jr. \& W. L. Culberson (1966): A third checklist of the lichens of the continental United States and Canada. Bryol. 69, 2:141-182.

HANSEN, K. (1962): Macrolichens from central West Greenland. Medd. om Gronl. 163:1-64.

KRUUSE, Chr. (1912): Rejser og botaniske undersøgelser i Øst-Grønland mellem 65 $30^{\circ}$ og 
$67^{\circ} 20^{\prime}$ i aarene 1898-1902. Samt Angmagssalik-egnens vegetation. Medd. om Gronl. 49: $1-304$.

LAMB, I. M. (1940): Lichens from East Greenland, collected by the Wager Expedition 19351936. Nytt. Mag. Naturvid. 80:263-286.

LYNGE, B. (1933): The lichens. Medd. om Gronl. 104, 5:1-15.

LYNGE, B. \& P. F. SChOlander (1932): Lichens from North East Greenland. 1. Skr. Svalb. og Ishavet 41: 1-116. 